\title{
Je libo ceduli nebo plakát?
}

\author{
Karolína Stehlíková
}

Výstava Račte vstoupit do divadla, Národní muzeum Praha. 13. 12. 2019 - 31. 3. 2020.

Před koncem roku 2019 byla v Národním muzeu v Praze otevřena ambiciózní výstava připravená kurátory Divadelního oddělení této instituce (hlavní autorka Markéta Trávníčková). ${ }^{1}$ Její název Račte vstoupit do divadla odkazoval ke skutečnosti, že základním výstavním exponátem, který měnil v průběhu století svou podobu, byla tzv. divadelní cedule - tedy na papíru zprostředkovaná zprvu převážně textová informace vztahující se ke konkrétnímu představení, jejíž hlavní funkcí bylo informovat potenciální diváky o konání určité divadelní události.

Protože divadelní cedule byly určeny k vnímání zrakem, koncipovali autoři celou výstavu jako vizuálně poutavé putování česko-německými divadelními dějinami od roku 1647 až do 60. let 20. století počínaje periochami řádových divadel přes cedule zvoucí na divadelní události v 18. a 19. století, dvojjazyčné plakáty z doby nacistické okupace až po graficky výmluvné plakáty malých scén z doby politického tání v 60. letech minulého století. Architekti výstavy (architektonické řešení Tomáš Bílek a tbi.

1 Dodejme, že výstava a katalog vznikly za finanční podpory Ministerstva kultury ČR v rámci projektu Cesta $k$ divadlu a jde tedy o laické i odborné veřejnosti určený výstup rozsáhlého výzkumného úkolu, na němž spolupracuje několik institucí. Vývoj metodiky a specifických nástrojů pro uchování, exploataci a zpřístupnění historických divadelních cedulí se zvláštním zřetelem ke sbírkovým fondům Národního muzea v Praze a Moravského zemského muzea v Brně byl podpořen Programem aplikovaného výzkumu a vývoje národni a kulturni identity (NAKI II), c. DG16P02B008 (2016-2020). architekti) zorganizovali vystavovaný materiál chronologicky do dvanácti vypouklých kójí připomínajících divadelní lóže.

Aby výstava nebyla jednotvárná, doplnili kurátoři cedule s popisky dalšími artefakty jako například dochovanými kostýmy (k zhlédnutí byl například první kostým Francka z Maryši bratří Mrštíkových), vzácnými rukopisy (tzv. pařížská verze Čapkovy hry Loupežnik), scénografickými modely (např́ílad Wachsmannovy modely $\mathrm{k}$ inscenacím Osvobozeného divadla), bustami význačných osobností, ale i diváckými proprietami typu divadelních kukátek a vějírư (včetně dobových kuriozit $\mathrm{v}$ podobě pokladničky ve tvaru budovy Národního divadla). Výstavu doplnila také interaktivní specializovaná mapa uložení cedulí v českých a moravských muzeích, knihovnách a archivech, která bude $\mathrm{v}$ budoucnu sloužit především odborníkům, pro něž tento elektronicky uspořádaný archiv představuje přímo badatelský poklad. Pro děti byl připraven prostor věnovaný loutkovému divadlu s hracími prvky a také koutek, kde se mohly převléct do divadelního kostýmu a pořídit si originální fotografii.

Jak tvưrci uvedli hned na počátku expozice, cedule měly kromě propagační funkce hodnotu také jako výtvarný artefakt, který mohl mít různorodé grafické pojetí - od převážně textových barokních cedulí ke graficky rafinovaně pojednaným plakátům, jež jsou příznačné pro století dvacáté. Tento fakt si návštěvník nejlépe uvědomil právě tehdy, když spatřil nejrưz- 


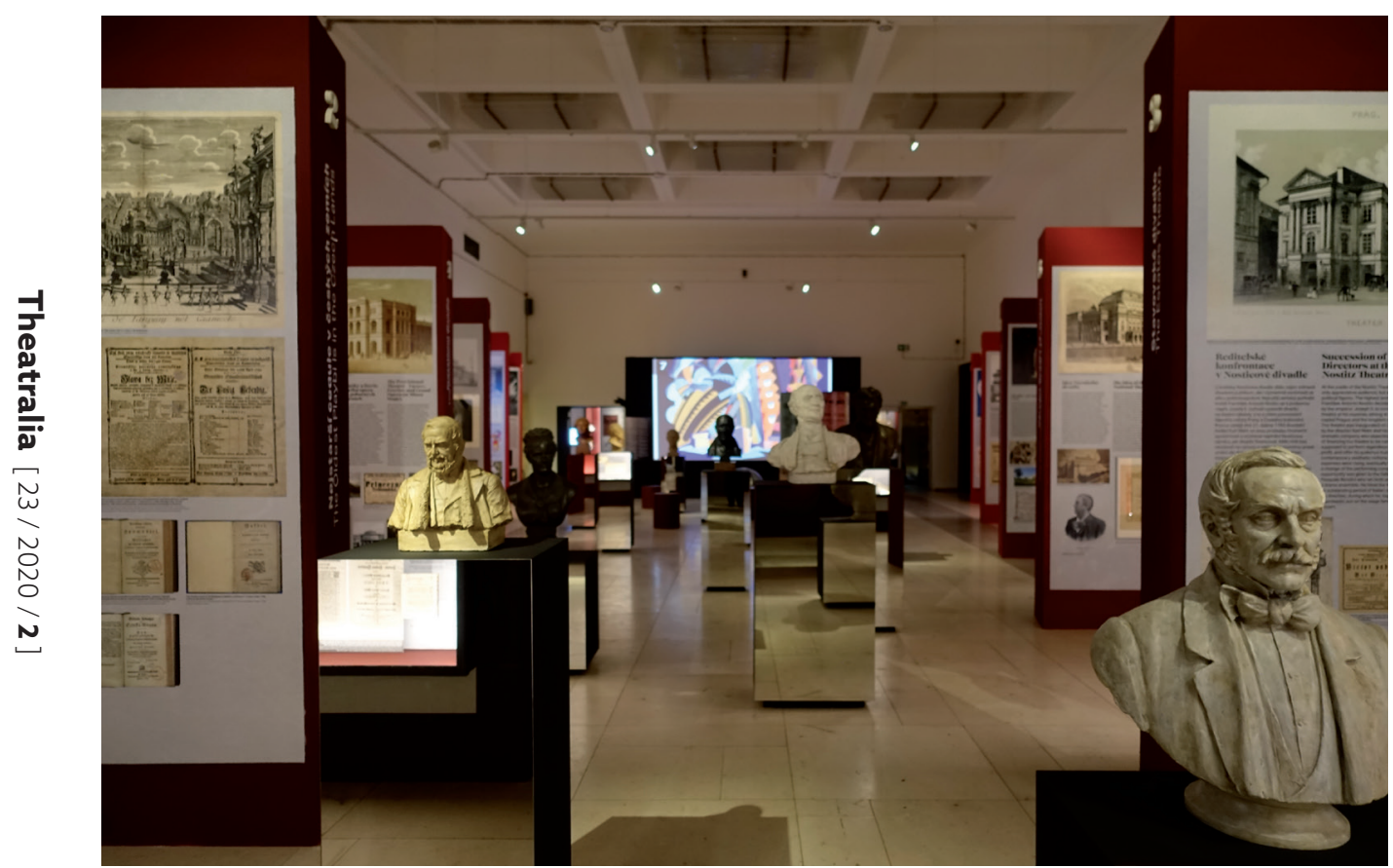

Obr. 1: Pohled do výstavy v Národním muzeu. Foto archiv Národního muzea.

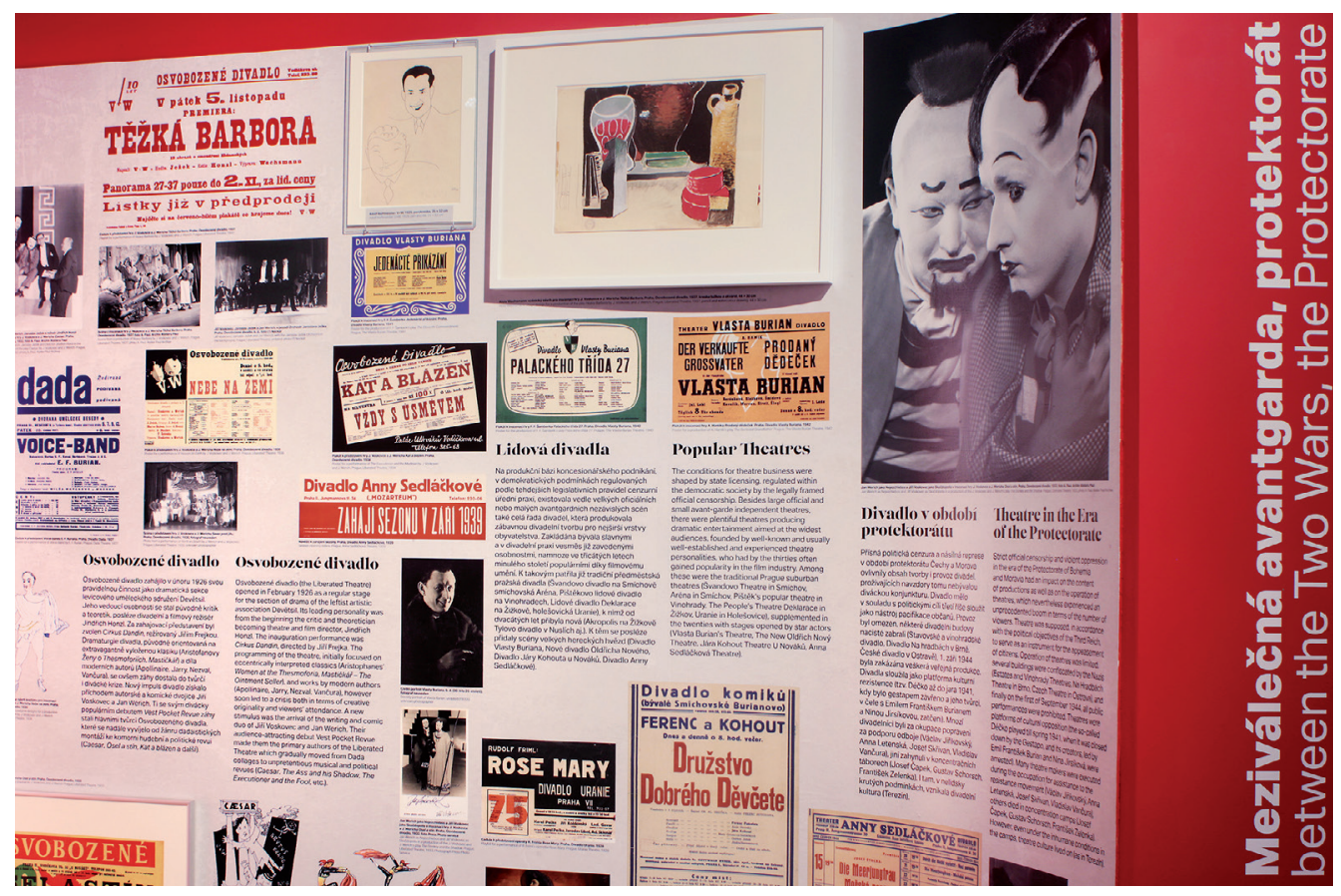

Obr. 2: Kóje věnovaná meziválečnému divadlu a divadlu v období protektorátu. Foto archiv Národního muzea. 


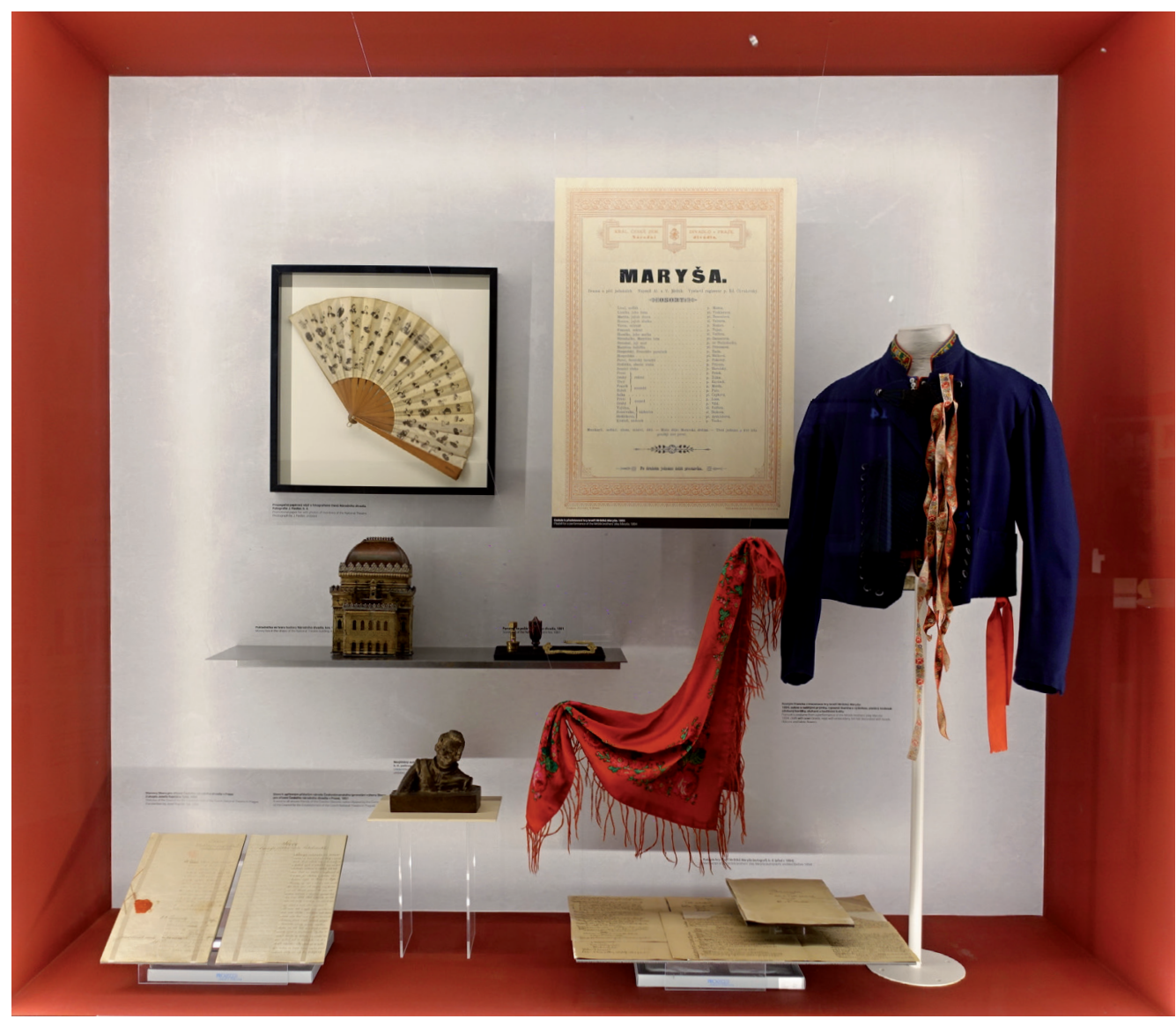

Obr. 3: Vitrína s artefakty. Foto archiv Národního muzea.

nější typy cedulí vystavené vedle sebe. V tu chvíli teprve vyniklo, jaký typ informací bylo možné na cedulích nalézt, kdy začaly divadlo „prodávat“ obrázky, od kdy se na plakátech shledáme s reklamou nebo jakým způsobem používaly jednotlivé scény ve 20. století divadelní plakát k definování vizuálního stylu svého divadla.

Kurátorský tým vytvořil také zjednodušenou podobu výstavy trvale dostupnou na internetu, ${ }^{2}$ která je určena primárně starším dětem. Pomocí načteného komentáře kombinovaného $\mathrm{s}$ fotografiemi vy-

$2 \mathrm{~K}$ nalezení na adrese https://exhibition.indihu.cz/view/racte-vstoupit-do-divadla/start. braných, na výstavě fyzicky dostupných artefaktů jsou mladším návštěvníkům v několika kapitolách přehledně podány dějiny českého divadla včetně závěrečného kvízu, který ověřuje, kolik si z výkladu zapamatovali.

K výstavě vyšla také stejnojmenná publikace, jež je spíše než katalogem široce koncipovaným odborným sborníkem. V př́íspěvku Markéty Trávníčkové „Sbírka cedulí a plakátů Divadelního oddělení Národního muzea" se lze dočíst, že sbírka, z níž výstava čerpá, obsahuje celkově kolem 400000 kusů plakátů a cedulí... 
Výstava se měla na podzim roku 2020 přestěhovat do Brna. Plánovalo se její doplnění o artefakty z archivu Oddělení dějin divadla Moravského zemského muzea. Vývoj situace v souvislosti s šírením viru Covid-19 však kurátory přiměl ke změně plánu spočívající v př́pravě interaktivní verze výstavy, která je od září 2020 kompletně dostupná na internetu (viz http:// ractevstoupit.mzm.cz/). Virtuální prohlídku výstavou zde doplňují přepisy výkladů z jednotlivých panelů (v českém i anglickém jazyce), možnost zvětšit vybrané artefakty a také hudební doprovod v podobě audio ukázek z inscenací ze 20. století. Tak- to připravená výstava je skvělým počinem, který ocení zvláště pedagogové a studenti divadelních škol, teatrologie, bohemistiky a příbuzných oborů, protože může sloužit jako pohodlná výuková pomůcka.

Výstava Račte vstoupit do divadla představuje pozoruhodný a esteticky půvabný nástroj $\mathrm{k}$ nahlédnutí dějin divadla na našem území. Výsledek je překvapivě plastický, byt základním výstavním exponátem je obyčejný papír s několika slovy, který naši předci poté, co informačně posloužil, často bez sentimentu recyklovali na obalový materiál, pokud jej z plakátovacích ploch rovnou nestrhaly rozmary počasí. 